Kazimierz Łastawski

$11 / 2019$

\title{
Polityka wschodnia Polski w publicystyce paryskiej „Kultury” i działalności Instytutu Literackiego
}

D o zakończeniu II wojny światowej geopolityczne położenie Polski uległo zasadniczej zmianie. Z kraju stanowiącego przez wieki ostatni bastion cywilizacji zachodniej Polska została zwasalizowana przez Moskwę, a Ukraina, Litwa i Białoruś stały się republikami imperium radzieckiego. W czasie dominacji moskiewskiej nad Europą Wschodnią uzależniony rząd Polski stracił możliwości wpływu na wydarzenia postępujące na wschód od tzw. linii Curzona. Próby oddziaływań ze strony polskiej emigracji politycznej w Londynie nie miały praktycznego znaczenia ani na sytuację w kraju, ani na kształt wschodniej granicy. Nowe rozwiązania $\mathrm{w}$ polityce wschodniej Polski formułował paryski ośrodek emigracyjny, wykorzystujący łamy paryskiej „Kultury” i działania Instytutu Literackiego, kierowane przez Redaktora Jerzego Giedroycia. Ośrodek paryski zabiegał przede wszystkim o „znormalizowanie stosunków polsko-rosyjskich i polsko-niemieckich, przy jednoczesnym bronieniu niepodległości Ukrainy, Białorusi i państw bałtyckich i przy ścisłej współpracy z nimi"1. Poglądy Giedoycia podzielały treść licznych publikacji najwybitniejszego publicysty „Kultury” Juliusza Mieroszewskiego. Według blisko z nimi współpracującego Krzysztofa Pomiana był on, ,partnerem, doradcą, powiernikiem i przyjacielem - słowem, alter ego Jerzego Giedroycia"2.

Problemy polskiej polityki wschodniej po II wojnie światowej prezentowało wielu autorów o zróżnicowanych orientacjach. W latach PRL-u prezentacja tej problematyki w kraju była utrudniona działaniami cenzury. Na emigracji występowały różnice stanowisk, zwłaszcza między Londynem i Paryżem. Zarówno w ośrodku paryskim, jak i później wśród środowisk opozycyjnych w kraju występowało na ogół przyjazne odniesienie do Ukraińców, Litwinów i Białorusinów. Sporne kwestie w sprawach polityki wschodniej po II wojnie światowej zauważa się także w ostatnio wydanej pracy zbiorowej pod redakcją Stanisława Bielenia Polityka wschodnia Polski - między fatalizmem geopolitycznym a klątwa niemocy (Pułtusk-Warszawa 2019). Natomiast wielostronne ujęcie tej polityki przynosi obszerna monografia Pawła Kowala zatytułowana Testament Prometeusza. Źródła polityki wschodniej III Rzeczypospolitej (Warszawa-Wojnowice 2019). ${ }^{3}$

Prezentowany artykuł skupia główną uwagę na publikacjach paryskiej „Kultury” od 1947 roku do śmierci redaktora Giedroycia w 2000 roku. Prace autorów ośrodka paryskiego najszerzej prezentuje dwutomowa antologia zatytułowana Wizja Polski na łamach „Kultury” 1947-1976, przygotowana do druku oraz opatrzona wstępem, przypisami i indeksem przez Grażynę Pomian, a wydana w Lublinie w 1999 roku (T.1 s. 441, T.2 s. 455).

\footnotetext{
${ }^{1}$ J. Giedroyc, Autobiografia na cztery ręce. Warszawa 1995, s.228.

${ }^{2}$ K. Pomian, W kręgu Giedroycia, Warszawa 2000, s. 76.

${ }^{3} \mathrm{Na}$ temat ujęć doktryny Giedroycia przez specjalistów polskich prof. Paweł Kowal przeprowadził obszerną ankietę w ,Sprawach Międzynarodowych” 2008 nr. 3-4.
} 
1. „Kultura” paryska - ośrodek wolnej myśli polskiej

Redaktor Jerzy Giedroyc skupił wokół „Kultury” i Instytutu Literackiego wielu autorów. Najbardziej znaczący z nich to: Juliusz Mieroszewski, Andrzej Bobkowski, Jerzy Stępowski, Józef Czapski, Konstanty A. Jeleński, Bohdan Osadczuk i Leopold Unger. Upowszechniał dorobek wybitnych pisarzy emigracyjnych: Witolda Gombrowicza, Czesława Miłosza i Gustawa Herlinga-Grudzińskiego, prace autorów z kraju oraz dysydentów ze Wschodu. Organizował również przekłady i wysyłkę do kraju najnowszych prac humanistycznych, filozoficznych i politologicznych autorów zachodnich: Alberta Camusa, Raymonda Arona, George Orwella i Jamesa Burnhama. Grażyna Pomian dowodzi, iż „Na emigracji było wiele pism, które broniły wartości narodowych, spuścizny kulturalnej oraz walczyły z komunizmem, ale jedynie „Kultura” stała się symbolem niezależnej myśli wolnej Polski"4. Budowała mosty wzajemnego poznania i porozumienia narodów, mimo przeciwności politycznych i materialnych oraz uprzedzeń społecznych.

W warunkach blokowego podziału Europy i zniewolenia Polski Giedroyc utworzył i rozwinął w Paryżu szczególny ośrodek koncepcyjny, programowy i organizacyjny z zadaniem wpływu na społeczeństwo polskie oraz środowiska polskiej emigracji politycznej. „Swoim pojmowaniem racji stanu był związany z Drugą Rzeczpospolitą. A jednocześnie po wojnie potrafił się ustrzec wszelkiego epigoństwa. Umiał otworzyć się na zrozumienie nowej epoki z jej prądami i przemianami, odrębność języka i pojęć. Stworzył wydawnictwo atrakcyjne dla współczesnych, zrozumiałe dla Polaków w kraju, a jednocześnie nie zrywające z tym, co z tradycji było ważne do przeniesienia na przyszłość." 5 . Czynił wysiłki, aby poznawać bieżące życie kraju, nurtujące naród problemy i nastroje oraz dążył do inspirowania krajowych elit kontestujących. Postanowił rozwijać działania ,przede wszystkim na obszarze kultury: literatury, filozofii, historii, nauki, sztuki - słowem tych dziedzin, które kształtują wierzenia zbiorowe i postawy jednostek"'.

Prezentowane przez „Kulturę” propozycje dla Polski zakładały nowe ukształtowanie granic, zmiany ustrojowe, problemy uwspółcześnienia państwa polskiego i kształtowanie wizji rozwoju w nowym otoczeniu międzynarodowym ${ }^{7}$. Zakładały nowe zdefiniowanie polskiej polityki między Niemcami i Rosją. Mieroszewski formułując „ABC polityki „,Kultury” pisał, iż jej celem ,jest definiowanie interesów państwowo - narodowych oraz szukanie dróg maksymalnego ich zaspokojenia i zabezpieczenia"8. Wzywał do odrzucenia dawnych koncepcji politycznych i tworzenia nowych w oparciu o analizę realnej rzeczywistości europejskiej ${ }^{9}$. Postulował ograniczenie rozważań o przeszłości, a perspektywy dla polskiego interesu narodowego upatrywał $\mathrm{w}$ rozszerzeniu zainteresowania narodu sprawami teraźniejszości i przyszłości. Uważał losy Polski za nieodłączne od losów Europy i proponował ściślejsze ujmowanie spraw polskich $\mathrm{w}$ powiązaniu $\mathrm{z}$ interesami europejskimi ${ }^{10}$. Poszukiwał możliwości wyzwolenia Polaków z zależności od imperium moskiewskiego, ale popierał zarazem wszelkie działania, które mogłyby polepszać los narodu polskiego.

\footnotetext{
${ }^{4}$ G. Pomian, Między legenda a historia [w:] Wizja Polski na łamach „,Kultury” 1947-1976, Lublin 1999, T 2, s. 11.

${ }^{5}$ A. Friszke, Jerzego Giedroycia praca u podstaw (1956-1976), [w] Spotkania z paryska „Kultura”” Warszawa 1995 , s. 32.

${ }^{6}$ K. Pomian, W kręgu Giedroycia, op. cit. s. 24.

${ }^{7}$ K. Łastawski „Racja stanu Rzeczypospolitej Polskiej, Warszawa 2000, s. 12-25; K. Skubiszewski, Polska racja stanu „Ad Meritum”, 1996, nr 3, s. 1-3.

${ }^{8}$ J. Mieroszewski, ABC polityki „Kultury” [w:] Finat klasycznej Europy. Lublin 1997, s. 246.

${ }^{9}$ Ibidem, s. 247.

${ }^{10}$ J. Mieroszewski, O reformę „zakonu polskości [w:] Finat klasycznej Europy, op. cit., s. 98-99.
} 
W latach najsilniejszej konfrontacji zimnowojennej „Kultura” zajmowała stanowisko podobne antykomunistycznej emigracji londyńskiej. Wraz ze zmianami europejskimi po śmierci Stalina publikacje „Kultury” różnicują się z poglądami ugrupowań polskiej emigracji politycznej w Londynie. Podobnie jak cała emigracja polityczna, „Kultura” była zdeklarowanym przeciwnikiem komunizmu, lecz proponowała bardziej tolerancyjne spojrzenie na zmiany zachodzące w Polsce, aniżeli centrum emigracji londyńskiej głoszące ideę „narodu na wygnaniu” 11 . Publicystyka „Kultury” potępiała służalcze wobec Moskwy działania władz warszawskich, ale też dystansowała się od „niezłomnych” polityków emigracyjnych w Londynie ${ }^{12}$. Schematyczne i skrótowe porównanie trzech głównych stanowisk polskich po II wojnie światowej prezentuje Tabela 1.

\section{Stanowisko paryskiej „Kultury” wobec wladz PRL}

i ośrodka polskiej emigracji politycznej w Londynie

\begin{tabular}{|c|c|c|c|}
\hline $\begin{array}{l}\text { Zasadnicze } \\
\text { problemy }\end{array}$ & $\begin{array}{c}\text { Stanowisko władz } \\
\text { PRL }\end{array}$ & $\begin{array}{c}\text { Stanowisko } \\
\text { „Kultury” paryskiej }\end{array}$ & $\begin{array}{l}\text { Stanowisko ośrodka } \\
\text { londyńskiego }\end{array}$ \\
\hline Konstytucja & $\begin{array}{l}\text { Konstytucja } \\
\text { „stalinowska” } \\
\text { z } 1952 \text { r. }\end{array}$ & $\begin{array}{l}\text { Potrzeba tworzenia } \\
\text { nowej Konstytucji }\end{array}$ & $\begin{array}{c}\text { Przywrócenie } \\
\text { Konstytucji z } 1935 \text { r. }\end{array}$ \\
\hline $\begin{array}{c}\text { Preferencje dział } \\
\text { ań }\end{array}$ & $\begin{array}{l}\text { Ograniczenie } \\
\text { wpływów } \\
\text { kapitalizmu }\end{array}$ & $\begin{array}{c}\text { Ograniczenie } \\
\text { wpływu USA i } \\
\text { ZSRR w Europie }\end{array}$ & $\begin{array}{l}\text { Ścisła współpraca z } \\
\text { USA i Wielką Brytanią }\end{array}$ \\
\hline $\begin{array}{l}\text { Zachodnia } \\
\text { granica Polski }\end{array}$ & $\begin{array}{l}\text { Odra - Nysa } \\
\text { Łużycka }\end{array}$ & $\begin{array}{l}\text { Odra - Nysa } \\
\text { Łużycka }\end{array}$ & Odra - Nysa Łużycka \\
\hline $\begin{array}{l}\text { Wschodnia } \\
\text { granica Polski }\end{array}$ & Linia Curzona & $\begin{array}{l}\text { Linia Curzona } \\
\text { (od } 1953 \text { r.) }\end{array}$ & $\begin{array}{l}\text { Granica traktatu } \\
\text { ryskiego z 1921roku }\end{array}$ \\
\hline Ustrój polityczny & $\begin{array}{l}\text { „Demokracja } \\
\text { ludowa" }\end{array}$ & $\begin{array}{c}\text { Modyfikacja ustroju } \\
\text { II RP }\end{array}$ & $\begin{array}{c}\text { Przywrócenie ustroju II } \\
\text { RP }\end{array}$ \\
\hline System partyjny & $\begin{array}{c}\text { Hegemoniczna rola } \\
\text { PZPR }\end{array}$ & $\begin{array}{l}\text { Tworzenie systemu } \\
\text { wielopartyjnego }\end{array}$ & $\begin{array}{l}\text { Przywrócenie systemu } \\
\text { partyjnego II RP }\end{array}$ \\
\hline
\end{tabular}

${ }^{11}$ A. Friszke, Życie polityczne emigracji, Warszawa 1999, s. 25-51,106-129.

${ }^{12}$ W. niektórych sprawach do stanowiska ideowo - politycznego „Kultury zbliżał się londyński Polski Ruch Wolnościowy Niepodległość i Demokracja, kierowany przez Rowmunda Piłsudskiego (redaktora pisma „Trybuna”). 


\begin{tabular}{|c|c|c|c|}
\hline Sojusznicy & $\begin{array}{c}\text { ZSRR i kraje } \\
\text { "demokracji } \\
\text { ludowej" }\end{array}$ & $\begin{array}{c}\text { Sąsiedzi i państwa } \\
\text { zachodnie }\end{array}$ & $\begin{array}{c}\text { Mocarstwa zachodnie } \\
\text { (USA, Wielka } \\
\text { Brytania, Francja) }\end{array}$ \\
\hline
\end{tabular}

Tabel 1. Źródło: opracowanie autora.

\section{Nowa polityka wschodnia „Kultury” (koncepcja ULB).}

Najbardziej charakterystyczną częścią strategii politycznej „Kultury” była idea ULB, stanowiąca podstawy przyszłej polityki wschodniej. Jej istota to:

- akceptacja wschodniej granicy Polski zgodnie z decyzjami mocarstw,

- wspieranie przez Polskę niepodległości Ukrainy, Litwy i Białorusi,

- poszukiwanie zbliżenia z Moskwą.

Idea ULB nawiązywała do idei prometejskiej II Rzeczypospolitej, która zakładała ewolucyjne przekształcenie imperium radzieckiego i powstanie niepodległych państw za wschodnią granicą Polski ${ }^{13}$. Po zakończeniu II wojny światowej Związek Radziecki zwiększył swoje wpływy terytorialne i włączył ten obszar w swoje granice. Mimo rozszerzonego panowania Moskwy Giedroyc i Mieroszewski opowiedzieli się za działaniami mogącymi prowadzić do rozpadu imperium radzieckiego, a zwłaszcza za dążeniami wyzwoleńczymi narodów Ukrainy, Litwy i Białorusi. Zaakceptowali powojenne granice Polski na wschodzie, by $\mathrm{w}$ ten sposób umożliwić pojednanie między Polską a Ukrainą, Litwą i Białorusią oraz złagodzenie wielowiekowego sporu z Rosją. Polską emigrację polityczną i wielu Polaków w kraju najbardziej zaszokowała decyzja Giedroycia o uznaniu nowej granicy wschodniej oraz o przekazaniu zwierzchnictwa nad Lwowem Ukraińcom, a nad Wilnem -Litwinom ${ }^{14}$. Decyzja ta była zbieżna z postanowieniami Wielkiej Trójki, ale wówczas rozmijała się z poglądami większości Polaków.

W 1974 roku Mieroszewski zaprezentował programowy esej w sprawach ULB pt. Rosyjski „kompleks Polski” $i$ obszar ULB. Odrzucał w nim eksponowaną przez ośrodek londyński możliwość powrotu Polski do granic wschodnich z lat międzywojennych. Przypominał, że na obszarze ULB przez wieki następowały zmagania polsko-rosyjskie, a po jego opanowaniu Moskwa umacniała swą pozycję wobec Polski, lekceważąc interesy narodowe Ukrainy, Litwy i Białorusi. Powyższy obszar przez długi czas był „kością niezgody” między Polską i Rosją , determinował formę stosunków polsko-rosyjskich, skazując nas albo na imperializm, albo na satelictwo"15.

Mieroszewski zdecydowanie opowiadał się za potrzebą uwzględniania przez Polaków interesów narodowych Ukraińców, Litwinów i Białorusinów. Dla poszukiwania porozumienia z Rosją proponował, by strona polska zrezygnowała „raz na zawsze” z Wilna, Lwowa i jakichkolwiek dążeń, które zmierzałyby do dominacji polski nad narodami ULB. „Nie wierzę - pisał - byśmy byli kiedykolwiek w możności odepchnąć Rosję z rogatek Przemyśla pod Smoleńsk. Uważam również, że system powyższy - choć głęboko historycznie zakorzeniony jest dziś anachronizmem, barbarzyńskim anachronizmem. Ukraińcy, Litwini i Białorusini w XX wieku nie mogą być pionkami w historycznej grze polsko-rosyjskiej"16. Poglądy

\footnotetext{
${ }^{13}$ A. S. Kowalczyk, ,Kultura”, Wrocław 1999, s. 151-152.

${ }^{14}$ Decyzja ta nastąpiła po zasadniczych rozważaniach na początku lat pięćdziesiątych.

${ }^{15}$ J. Mieroszewski, Rosyjski , kompleks Polski” i obszar ULB [w:] Wizja Polski, op. cit., s. 281.

${ }^{16}$ Ibidem, s. 286.
} 
Mieroszewskiego i Giedroycia były trudne do przyjęcia przez Polaków, bo w ich świadomości jagiellońskiej Lwów i Wilno były centrami kultury i bastionami polskości na Wschodzie. Większość powojennej emigracji politycznej wywodziła się ze Wschodu i trudno jej było pogodzić się z myślą, że ich strony rodzinne pozostaną na zawsze poza granicami Polski. Wycofanie ze Wschodu oceniali jako tragedię osobistą i narodową.

Praca Mieroszewskiego Rosyjski „kompleks Polski” $i$ obszar ULB formułowała strategiczne założenia zmian politycznych i terytorialnych za wschodnią granicą nowej Polski. Wyprzedzała myślenie wielu środowisk polskich, które ceniły jagiellońskie zdobycze na Wschodzie. Wybitny znawca problemu polityki wschodniej Polski Paweł Kowal ocenia idee ULB Juliusza Mieroszewskiego za ,jeden z najważniejszych tekstów w historii kształtowania się polskiej polityki wschodniej"17.

Giedroyc szczególnie zabiegał o wsparcie dla rozwoju niepodległej Ukrainy, bo w jej umocnieniu upatrywał najważniejszy czynnik osłabienia imperialnych wpływów Moskwy w Europie Wschodniej. Wyrażał solidarność z tradycją niepodległościowego ruchu ukraińskiego atamana Semena Petlury ${ }^{18}$. W jego ocenie Ukraina dominowała ponad możliwościami politycznymi, ekonomicznymi i demograficznymi Litwy i Białorusi. Wprowadził na łamy „Kultury” Kronikę ukraińska, stanowiącą źródło wiedzy o losach ukraińskiej emigracji, a także o wydarzeniach na radzieckiej Ukrainie. Opublikował w języku ukraińskim antologię narodowych pisarzy ukraińskich Roztrilane widrożenija (Rozstrzelane odrodzenie) pod redakcją Jurija Ławrynienki oraz dokumenty z lat 1956-1968 ukazujące przeciwdziałanie rusyfikacji ${ }^{19}$. Z inicjatywy Giedroycia ukazała się w 1977 roku wspólna deklaracja emigrantów czeskich, polskich, ukraińskich, rosyjskich i węgierskich w sprawie niepodległości Ukrainy, oraz innych narodów uzależnionych przez Związek Radziecki ${ }^{20}$. Rozszerzała ona płaszczyznę dialogu emigrantów polskich z dysydentami reprezentującymi Europę Wschodnią.

Głównymi inspiratorami pojednania polsko-ukraińskiego na łamach „Kultury” byli: pisarz tłumacz poezji rosyjskiej, ukraińskiej i białoruskiej Józef Łobodowski oraz bliski współpracownik Giedroycia - ukraiński dziennikarz - Bohdan Osadczuk. Józef Łobodowski w obszernym artykule Przeciw upiorom przeszłości wzywał do wyciszenia kompleksów i urazów polsko-ukraińskich. „Czas byłby najwyższy - pisał Łobodowski - aby Polacy zrozumieli, że Ukraińcy są odrębnym narodem o takim samym prawie do samoistności, jakie przysługuje każdemu innemu narodowi. Że wiele cech ujemnych, które nas rażą albo dają się nam dotkliwie we znaki, powstało na skutek tragicznej historii i nienormalnego rozwoju kultury narodowej, stale krępowanej przez nieprzyjazne okoliczności. Że wreszcie zły to patriota, który sąsiadowi zza między odmawia takich samych uczuć patriotycznych, choćby z tym sąsiadem miał sto razy na pieńku” "21. W ślad za wysuniętą koncepcją ULB ośrodek „Kultury” rozwinął wydawanie książek dysydentów z radzieckiego imperium.

„Kultura” krytykowała komunizm i imperialną politykę Kremla na Wschodzie, potępiała sowietyzm, odgraniczając jego imperialne cele od trudnej sytuacji narodu rosyjskiego zdominowanego przez władze komunistyczne. Giedroyc publikował w Instytucie Literackim książki ukazujące złe cechy systemu sowieckiego m.in.: Józefa Czapskiego Na nieludzkiej ziemi, Gustawa Herlinga-Grudzińskiego Inny świat i Stanisława Swianiewicza $W$ cieniu

\footnotetext{
${ }^{17}$ P. Kowal, Testament Prometeusza. Źródła polityki wschodniej III Rzeczypospolitej, Warszawa-Wojnowice 2019 , s.86.

${ }^{18}$ A. S. Kowalczyk, op. cit., s. 160.

${ }^{19}$ J. Giedroyc, op. cit., s.184; A. S. Kowalczyk, op. cit., s. 160.

20 R. Habielski, Życie społeczne i kulturalne emigracji, Warszawa 1999. s. 291.

${ }^{21}$ J. Łobodowski, Przeciw upiorom przeszłości [w:] Wizja Polski, op. cit., s. 196.
} 
Katynia $^{22}$ „Zadaniem polskiej polityki wschodniej - pisał Mieroszewski w tekście Polska „Ostpolitik” - winno być rozbudzanie i potęgowanie wszystkich sił odśrodkowych w Sowietach i scementowanie wspólnego frontu narodów ujarzmionych przez Sowiety - Rosjan nie wyłączając" ${ }^{23}$. Wraz ze zjawiskami odprężenia w stosunkach europejskich w publikacjach „Kultury” zaczęto liczyć na ewolucję polityki moskiewskiej i ułożenie relacji z Rosją na nowych zasadach. Juliusz Mieroszewski i Jerzy Giedroyc zbliżenie z Rosjanami rozpoczęli od oddolnego porozumienia środowisk naukowych, literackich i artystycznych obu krajów ${ }^{24}$. Starali się przekonać Polaków, że ruch dysydencki w Związku Radzieckim ma znaczenie dla narodów Europy Wschodniej. Giedroyc podjął wydawanie z Bibliotece „Kultury” niezależnej literatury rosyjskiej, zwłaszcza Borysa Pasternaka i Aleksandra Sołżenicyna, pomagał w uruchomieniu dysydenckiego pisma rosyjskiego „Kontynent” pod redakcją Władimira Maksimowa i przygotował wydawanie okazowych numerów „Kultury” w języku rosyjskim² ${ }^{25}$.

\section{Realizacja idei „Kultury” w polityce III Rzeczypospolitej.}

W realizacji polityki wschodniej po 1989 roku doszło do pewnej syntezy dorobku intelektualnego" Kultury", praktycznych wysiłków Instytutu Literackiego, inicjatyw władz katolickich oraz dążeń polskich środowisk opozycyjnych. Trudny do oceny wpływ miały także oddziaływania USA i Europy Zachodniej. Giedroyc inspirował wielu autorów, kierował pracami redakcyjnymi „Kultury” i „Zeszytów Historycznych” /od 1962 roku/, organizował serie wydawnicze, prowadził bardzo bogatą korespondencję, przesyłał do kraju wydawnictwa Instytutu i podejmował wiele inicjatyw upowszechniających idee niezależnej Polski ${ }^{26}$. Idee „Kultury” w sprawach polityki wschodniej inspirowały działania opozycji krajowej, zwłaszcza Polskiego Porozumienia Niepodległościowego, Komitetu Obrony Robotników i Konfederacji Polski Niepodległej. Po rozwinięciu w kraju działalności opozycyjnej „Kultura” - zdaniem Iwony Hofman - powoli obracała się w ,trybunę prześladowanej w Polsce opozycji demokratycznej" 27 . Na jej łamach drukowano odezwy, deklaracje i apele oraz informowano o przebiegu strajków, manifestacji i represjach wobec opozycji ${ }^{28}$. Na spotkania z Giedroyciem do Paryża przybywali działacze opozycji krajowej i zwiększył się także udział autorów z kraju w publikacjach „Kultury”.

Powstanie NSZZ „Solidarność” spełniło nadzieje Jerzego Giedroycia na powstanie ruchu wolnościowego, łączącego robotników i inteligencjęę. Paweł Kowal wskazuje, że podbudowę programową działań Solidarności w znacznej części stanowiły wybory publicystyki redagowanej przez Giedroycia ${ }^{30}$. Do koncepcji ULB paryskiej „Kultury” nawiązało przyjęte 8 września 1981 roku na I Zjeździe Delegatów NSZZ „Solidarność” w Gdańsku głośne „Posłanie do ludzi pracy Europy Wschodniej”, stanowiące swoisty apel do narodów krajów bloku wschodniego o podejmowanie podobnych działań opozycyjnych.

\footnotetext{
${ }^{22}$ J. Giedroyc, op. cit., s. 198.

${ }^{23}$ J. Mieroszewski, Polska „Ostpolitik” [w:] Finat... op. cit., s . 339; Por. P. Kowal, Testament Prometeusza, op. cit. s.193-198.

${ }^{24}$ J. Mieroszewski, Modele i praktyka, Paryż 1970, s. 28-29.

${ }^{25}$ A. S. Kowalczyk, op. cit., s. 156-157.

${ }^{26}$ A. M. Supruniuk, Zobaczyć inna Polskę. Pomoc paryskiego Instytutu Literackiego dla Polski w latach $1946-$ 1990, Toruń 2011, s. 7-16; K. Pomian, op. cit., s. 116-117.

${ }^{27}$ I. Hofman, Stan badań recepcji „,Kultury” [w:] „,Kultura i jej odbiór w Polsce, Torun-Paryż 2017, s. 15.

${ }^{28}$ Ibidem, s. 15.; I. Hofman, W kręgu oddziatywania paryskiej ,,Kultury”, „Przegląd Politologiczny”, 2006, nr 2, s. $151-160$.

${ }^{29}$ A. Friszke, Życie polityczne... op. cit., s.453.

${ }^{30}$ P. Kowal, Testament...op. cit., s. 195-203.
} 
Posłanie szokowało Moskwę, bo kojarzono go z ideami prometejskimi zmierzającymi do rozbicia ZSRR i przyznania wolności narodom imperium radzieckiego ${ }^{31}$.

Za jedną z pierwszych prób realizacji idei ULB można uznać konferencję polskoukraińską w Jabłonnie 4-5 maja 1990 roku (niemal dokładnie w 70 rocznicę podpisania porozumienia Piłsudskiego $\mathrm{z}$ atamanem Petlurą). W konferencji uczestniczyli politycy wolnej Polski i przywódcy opozycji ukraińskiej. ${ }^{32} \mathrm{~W}$ jej trakcie omawiano aktualne wówczas kwestie polsko-ukraińskie ${ }^{33}$. W liście do uczestników konferencji Giedroyc uznał ją ,za milowy krok w realizacji wizji polityki wschodniej Juliusza Mieroszewskiego"34.

Zbieżne z projektami polityki wschodniej ośrodka paryskiej opozycji było wspieranie katolików w państwach ULB pozostających pod wpływami cerkwi prawosławnej przez papieża Jana Pawła II. Z jego inspiracji prymas Polski Józef Glemp i polscy księża docierali do przedstawicieli polskiej mniejszości katolickiej na Wschodzie ${ }^{35}$. Bliskie współdziałanie papieża z prezydentem Ronaldem Reaganem wpłynęło na osłabienie imperium radzieckiego i miało też wpływ na odzyskanie przez Polskę wolności oraz ukształtowanie się polskiej polityki wschodniej. Według kompetentnej oceny Pawła Kowala wraz z rozpadem ZSRR zrealizowano główne założenia polskich idei prometejskich. Zaproponował on by nową linię polityczną Polski na Wschodzie określać jako „nowy prometeizm” lub „neoprometeizm”36.

Koncepcja ULB paryskiej „Kultury” została zrealizowana w ograniczonym zakresie. Szybki rozpad imperium radzieckiego zróżnicował charakter procesów wolnościowych na Ukrainie, Litwie i Białorusi. Część formułowanych na łamach „Kultury” propozycji nie wytrzymała próby czasu. Miesięcznik przeceniał możliwości wpływu Polski na wydarzenia za wschodnią granicą. Przeceniał też możliwości wpływu dysydentów rosyjskich na zmiany w Moskwie. Nie sprawdziły się też dążenia „Kultury”, by Polska mogła odegrać główną rolę w kształtowaniu nowej państwowości krajów $\mathrm{ULB}^{37}$. Zbyt silna pozostawała na tym terenie pozycja Moskwy i nie udało się doprowadzenie do partnerskiego ułożenia stosunków polskorosyjskich. Państwa ULB dalej pozostały pod wpływami gospodarczymi, politycznymi, militarnymi i językowymi Rosji. Doprowadziła ona do utworzenia na obszarze b. imperium Wspólnoty Niepodległych Państw ${ }^{38}$ i podejmowała dalsze działania do utrwalenia wpływów Rosji na całym obszarze poradzieckim.

Polska jako pierwsza uznała niepodległość Ukrainy w grudniu 1991 roku, ale nie mogła zmienić jej związków z Rosją, dla której Ukraina, była najbardziej znaczącym czynnikiem strategicznej pozycji Moskwy. Próby wpływania przez Polskę na orientację polityczną Ukrainy w ramach ogólnej strategii Zachodu przyniosły ograniczone efekty. Lepiej rozwinęła się polsko-ukraińska współpraca wojskowa. Najważniejszą inicjatywą we wschodniej polityce Polski było rozwinięcie (wraz ze Szwecją) propozycji Partnerstwa Wschodniego, obejmującego Białoruś, Mołdowę, Ukrainę, Armenię, Gruzję i Azerbejdżan. Inicjatywa ta miała służyć transponowaniu wartości Zachodu na kraje ULB, ale napotkała na silne przeciwdziałanie Rosji (wobec Ukrainy nawet z użyciem siły zbrojnej).

\footnotetext{
${ }^{31}$ K. B. Janowski, Źródła i przebieg zmiany politycznej w Polsce (1980-1989). Studium historycznopolitologiczne, Toruń 2003, s. 50.

${ }^{32}$ B. Osadczuk, Zbliżenie polsko-ukraińskie [w:] „Kultura” 1990 nr 6, s. 37-38.

${ }^{33}$ Delegacja ukraińska domagała się $\mathrm{m}$. in. potępienia przez polski parlament akcji przesiedleńczej „Wisła”.

${ }^{34}$ P. Kowal, Testament...op. cit., s. 534.

${ }^{35}$ Ibidem, s. 334-345.

${ }^{36}$ Ibidem, s. 100 .

${ }^{37}$ K. Łastawski, Polityka wschodnia Polski po odzyskaniu niepodległości [w:] Polityka wschodnia Polski-między fatalizmem geopolitycznym a klątwa niemocy, Pułtusk-Warszawa 2019, s. 26.

${ }^{38} \mathrm{Z}$ byłych republik ZSRR tylko Litwa, Łotwa i Estonia nie przyłączyły się do Wspólnoty.
} 
Białoruś, od objęcia w niej najwyższej władzy przez prezydenta Aleksandra Łukaszenkę w 1994 roku, rozwinęła ścisłą współpracę z Rosją. Jej gospodarowanie ułatwiło szerokie wykorzystanie rosyjskich surowców energetycznych. Doszło wkrótce do ogłoszenia wspólnego Związku Białorusi i Rosji. Ścisła współpraca białorusko-rosyjska wpłynęła na ochłodzenie stosunków polsko-białoruskich. Władze Białorusi usiłowały izolować się od Polski i stosowały represje wobec działaczy Związku Polaków na Białorusi ${ }^{39}$. Polska usiłowała przeciwdziałać temu poprzez działania dyplomatyczne oraz poszukiwanie wsparcia ze strony Unii Europejskiej, Ukrainy i Litwy. Niezbyt udane okazały się polskie oddziaływania medialne na społeczeństwo białoruskie. W osobie prezydenta Łukaszenki władze polskie nie chciały dostrzegać poważnego partnera ${ }^{40}$.

Stosunki polsko-litewskie po 1991 roku przybrały specyficzny charakter. Komplikowało je rozwinięcie przez Polaków na Litwie dążeń do tworzenia autonomicznej struktury w rejonie Wilna i Solecznik. Próby te wywołały krytykę litewskich władz, wśród których pozostawała dalej pamięć o polityce Piłsudskiego wobec Litwy w latach międzywojennych ${ }^{41}$. Korzystnie rozwijała się współpraca obu państw w Unii Europejskiej i NATO. Dobrze na ogół postępowała współpraca wojskowa, m.in. utworzono wspólną jednostkę wojskową, a polscy lotnicy uczestniczą w zabezpieczeniu litewskiej przestrzeni powietrznej. Przez cały czas, z różnym natężeniem, kształtowała się współpraca gospodarcza ${ }^{42}$. Skomplikowany problem stanowił dalej szczególny status Polaków na Litwie, prowadzący do kolejnych regulacji z władzami Litwy zaniepokojonych polskimi wpływami kulturowymi. Po ostatnich wyborach dwoje Polaków objęło stanowiska ministrów w rządzie Litwy.

Polskie działania w polityce wschodniej przyniosły ograniczone sukcesy, z każdym państwem ULB rozwijają się zmienne relacje. Najbardziej znacząca dla Polski Ukraina ma nieustabilizowany system polityczny i dominujące wpływy oligarchów. Napotkała na kryzysową sytuację po zajęciu Krymu przez Rosję i działania separatystów na wschodzie kraju, uzyskujących propagandowe i militarne wsparcie Rosji. Polska zdecydowanie wspierała nowe władze Ukrainy przeciwko działaniom Rosji. Należała do inicjatorów wprowadzenia przez NATO i UE sankcji przeciwko Moskwie ${ }^{43}$. W ostatnich kilku latach wzrosły jednak w Polsce nastroje niechętne Ukrainie, inspirowane przez „ultrapatriotów” obu państw.

Polska nie wypracowała długofalowej strategii w polityce wschodniej. Zbyt często polityka ta sprowadza się do doraźnego zarządzania kryzysami. Dziś państwa ULB mają poprawne relacje z Polską. Na ich działalność silniej wpływa Moskwa aniżeli Warszawa. Silniejsze są tam wpływy cerkwi, aniżeli katolicyzmu ${ }^{44}$. Na Ukrainie i na Białorusi występują też silne wpływy kultury i języka rosyjskiego. Specjalizujący się w polityce wschodniej Stanisław Bieleń pisze, iż „Rosja determinuje losy wszystkich zachowań międzynarodowych na poradzieckim Wschodzie" 45 . Polska polityka wschodnia jest przesiąknięta misyjnością, a silna ideologizacja stosunków Polski z krajami za wschodnią granicą przeważa nad chłodną kalkulacją interesów ${ }^{46}$. Zwłaszcza polityka wobec Rosji bazuje na urazach, historycznych resentymentach i emocjach, a nie na interesach.

\footnotetext{
${ }^{39}$ J. Tymanowski, Rola i znaczenie Republiki Białoruś we współczesnej Europie., Toruń 2017, s. 101-102.

${ }^{40}$ P. Kowal, Duch straszliwego realizmu „Nowa Europa Wschodnia” 2016, nr 1, s. 54-55.

${ }^{41}$ P. Kowal, Testament Prometeusza, op. cit., s. 540-543.

${ }^{42}$ Polska zakupiła największą na Litwie rafinerię Możejki.

${ }^{43}$ R. Sakwa, The Death Europe? Continental Fates after Ukraine „International Affairs”, 2015, nr 3, s. 553.

${ }^{44}$ M. J. Chodakiewicz, Międzymorze. Warszawa 2017, s. 294-297.

${ }^{45}$ S. Bieleń, O polskiej polityce wschodniej-aspekty poznawcze i praktyczne „Polityka Wschodnia” 2012, nr 1, s.12.

${ }^{46}$ K. Świder, „Wielcy gracze” na Wschodzie-implikacje dla polskiej polityki wschodniej [w:] Polityka wschodnia Polski, op. cit., s. 409.
} 
Działalność „Kultury” i Instytutu Literackiego wywarły pewien wpływ na formułowanie polityki III Rzeczypospolitej. Książki Instytutu i publicystyka „Kultury” przyczyniły się do wykształcenia stylu myślenia polskich elit opozycyjnych i pomogły w formułowaniu nowego programu władzy. Po 1989 roku wszystkie rządy polskie zaakceptowały podstawowe idee formułowane w Paryżu: nową konstytucję, zmieniony system partyjny, nowe granice kraju i wynegocjowane stosunki z sąsiadami. Część propozycji publicystów „Kultury” została wykorzystana w procesie pojednania Polski z narodami ULB i w poszukiwaniach nowego sposobu ułożenia stosunków między Warszawą i Moskwą. Idee „Kultury” miały też pewien udział w normalizacji stosunków polsko-niemieckich.

Polska polityka zagraniczna i bezpieczeństwa w latach III Rzeczypospolitej koncentrowała się na współpracy z Zachodem. Jej udział w polityce wschodniej był mniejszy głównie z powodu trudnych relacji z Rosją oraz słabości i zróżnicowania państw ULB. W tym czasie Rosja dystansuje się od zachodniego modelu rozwojowego, promując własne rozwiązania prawno-ustrojowe oraz ,euroazjatycką" tożsamość międzynarodową ${ }^{47}$. Na obszarze poradzieckim Moskwa wyraźnie dominuje i buduje system satelicki ${ }^{48}$. Polska natomiast preferuje stosunki z USA i stopniowo zwiększa swój udział w próbach tworzenia przez nie antyrosyjskiego kordonu sanitarnego $\mathrm{w}$ obszarze poradzieckim ${ }^{49}$.

Ośrodek paryski Jerzego Giedroycia kształtował zasady polskiego interesu narodowego ponad interesami różnych partii i koterii politycznych. Był zwalczany przez władze Polski Ludowej i w różnym stopniu doceniany w latach III Rzeczypospolitej. Propozycje formułowane w ośrodku „Kultury” i Instytutu Literackiego tylko w części zostały zrealizowane. Sam Giedroyc był wielkim autorytetem dla kilku pokoleń polskiej inteligencji, wizjonerem kreślącym nowe miejsce Polski w Europie. Jego wydawnictwa spełniły pożyteczną misję w kształtowaniu myślenia politycznego Polaków.

\section{Streszczenie:}

Praca analizuje podstawowe publikacje „Kultury” paryskiej na temat polskiej polityki wschodniej z lat 1947-2000 oraz opracowania przygotowane na powyższy temat. Prezentuje specyficzne usytuowanie ośrodka Jerzego Giedroycia wśród polskiej emigracji politycznej po II wojnie światowej oraz wysuwane przez niego propozycje nowego ułożenia stosunków Polski z sąsiadami. Ośrodek „Kultury” dobrze przyczynił się do wzbogacenia intelektualnego kadr tworzących III Rzeczpospolitą. Główną uwagę autor skupia na publikacjach i organizatorskich działaniach Redaktora Jerzego Giedroycia i jego najbliższego współpracownika Juliusza Mieroszewskiego.

\section{Słowa kluczowe:}

ULB: Ukraina, Litwa, Białoruś i Polska po II wojnie światowej, Jerzy Giedroyc, Juliusz Mieroszewski.

\section{Keywords:}

\footnotetext{
${ }^{47}$ M. Raś, Rosja $w$ debacie politycznej w Polsce [w:] Polityka wschodnia Polski, op. cit., s.53.

${ }^{48} \mathrm{~K}$. Świder, Rosyjska świadomość polityczna a Ukraina i Białoruś (po rozpadzie Związu Radzieckiego), Warszawa 2015, s. 119.

${ }^{49}$ S. Bieleń, Polska w grze politycznej Wschodu i Zachodu [w:] Polityka wschodnia Polski, op. cit., s. 420.
} 
ULB: Ukraine, Lithuania, Belarus and Poland after II World War, Jerzy Giedroyc, Juliusz Mieroszewski.

\section{Bibliografia:}

1. Bieleń S., O polskiej polityce wschodniej-aspekty poznawcze i praktyczne, „Polityka Wschodnia" 2012, nr 1, s.12.

2. Bieleń S., Polska w grze politycznej Wschodu i Zachodu [w:] Polska polityka wschodnia-między fatalizmem geopolitycznym a klatwa niemocy, Pułtusk-Warszawa 2019.

3. Chodakiewicz M. J., Międzymorze, Warszawa 2017.

4. Friszke A., Jerzego Giedroycia praca u podstaw (1956-1976) [w:] Spotkania z paryska „Kultura”, Warszawa, 1995.

5. Friszke A., Życie polityczne emigracji, Warszawa 1999.

6. Giedroyc J., Autobiografia na cztery ręce, Warszawa 1999.

7. Habielski R., Życie społeczne i kulturalne emigracji, Warszawa 1999.

8. Hofman I., Stan badań recepcji „,Kultury” [w:] Kultura i jej odbiór w Polsce, ToruńParyż 2017.

9. Hofman I., W kręgu oddziaływania paryskiej „Kultury”, „Przegląd Politologiczny” $2006 \mathrm{nr} 2$.

10. Janowski K. B., Źródła i przebieg zmiany politycznej w Polsce (1980-1989). Studium historyczno-politologiczne, Torun 2003.

11. Kowal P., Duch straszliwego realizmu, „Nowa Europa Wschodnia” 2016, nr 1.

12. Kowal P., Testament Prometeusza. Źródła polityki wschodniej III Rzeczypospolitej, Warszawa-Wojnowice 2019.

13. Kowalczyk A. S., Giedroyc i „Kultura”, Wrocław1999.

14. Łastawski K., Polityka wschodnia Polski po odzyskaniu niepodległości [w:] Polityka wschodnia Polski-między fatalizmem geopolitycznym a klątwa niemocy, PułtuskWarszawa 2019.

15. Łastawski K., Racja stanu Rzeczypospolitej Polskiej, Warszawa 2000.

16. Łobodowski J., Przeciw upiorom przeszłości [w:] Wizja Polski na łamach „Kultury” 1947-1976, Lublin 1999, T. 2.

17. Mieroszewski J., ABC polityki „Kultury” [w:] Finat klasycznej Europy, Lublin.

18. Mieroszewski J., Modele i praktyka, Paryż 1970.

19. Mieroszewski J., O reformę „zakonu polskości” [w:] Finat klasycznej Europy, Lublin 1997.

20. Mieroszewski J., Polska „,Ostpolitik” [w:] Finat klasycznej Europy, Lublin 1997.

21. Mieroszewski J., Rosyjski ,,kompleks Polski” i obszar ULB [w:] Wizja Polski na łamach „Kultury” 1947-1976, Lublin 1999, T. 2.

22. Osadczuk Bohdan, Zbliżenie polsko-ukrainskie „Kultura” 1990, nr 6, s. 37-38.

23. Pomian G., Między legendq a historia [w:] Wizja Polski na łamach „Kultury” 19471976, Lublin 1999, T. 2.

24. Pomian K., W kręgu Giedroycia, Warszawa 2000.

25. Sakwa R., The Death Europe? Continental Fates after Ukraine. „International Affairs” 2015, nr 3.

26. Supruniuk M. A., Zobaczyć Inna Polskę. Pomoc paryskiego Instytutu Literackiego dla Polski w latach 1946-1990, Toruń 2011. 
27. Świder K., „Wielcy gracze” na Wschodzie - implikacje dla polskiej polityki wschodniej [w:] Polityka wschodnia Polski-między fatalizmem geopolitycznym a klątwa niemocy, Pułtusk-Warszawa 2019.

28. Świder K., Rosyjska świadomość geopolityczna a Ukraina i Białoruś (po rozpadzie Związku Radzieckiego), Warszawa 2015.

29. Tymanowski J., Rola i znaczenie Republiki Białoruś we wspótczesnej Europie, Toruń 2017. 